Jurnal Politeknik Caltex Riau
http://jurnal.pcr.ac.id

\title{
Analisis Pengukuran Kinerja dengan Konsep Balance Scorecard pada PT Bumi Hijau Puri Persada
}

\author{
Elisa Silviana $^{1}$, Suci Nurulita ${ }^{2}$, Heri Ribut Yuliantoro ${ }^{3}$ \\ ${ }^{1}$ Program Studi Akuntansi, Politeknik Caltex Riau, email: elisasilviana20@gmail.com \\ ${ }^{2}$ Program Studi Akuntansi, Politeknik Caltex Riau, email: nurulitasuci@gmail.com \\ ${ }^{3}$ Program Studi Akuntansi, Politeknik Caltex Riau, email: heriry@pcr.ac.id
}

\begin{abstract}
Abstrak
Penelitian ini bertujuan untuk menganalisis pengukuran kinerja PT Bumi Hijau Puri Persada dengan konsep Balanced Scorecard. Data primer diperoleh dari jawaban kuesioner dan wawancara terhadap pelanggan dan karyawan PT Bumi Hijau Puri Persada. Data sekunder diperoleh dari laporan keuangan baik laporan laba rugi maupun laporan posisi keuangan PT Bumi Hijau Puri Persada periode tahun 20015-2017. Hasil penelitian ini menunjukkan bahwa kinerja PT Bumi Hijau Puri Persada secara keseluruhan cukup baik dengan nilai sebesar 0,24. Perspektif keuangan yang diukur dengan analisis rasio keuangan dinilai kurang baik dengan nilai $(-0,33)$ yang meliputi rasio likuiditas yang cukup baik, rasio solvabilitas yang kurang baik, rasio profitabilitas yang dikategorikan kurang baik, dan rasio aktivitas yang dikategorikan baik. Hasil penelitian pada perspektif pelanggan menunjukkan kinerja yang cukup baik dengan nilai 0,56 yang meliputi atribut produk dan jasa, citra perusahaan, dan hubungan dengan pelanggan. Perspektif bisnis internal juga menunjukkan kinerja yang cukup baik dengan nilai 0,57 yang meliputi proses inovasi, proses operasi, dan layanan purna jual. Selain itu, perspektif pertumbuhan pembelajaran dinilai cukup baik dengan nilai 0,57 yang meliputi kapabilitas karyawan, kapabilitas sistem informasi, dan motivasi, pemberdayaan, keselarasan.
\end{abstract}

Kata kunci: Pengukuran Kinerja, Balance Scorecard, Perspektif Keuangan, Perspektif Pelanggan, Perspektif Bisnis Internal, Perspektif Pertumbuhan Pembelajaran.

\begin{abstract}
This study aims to analyze the performance measurement of PT Bumi Hijau Puri Persada using Balanced Scorecard concept. The Primary data was obtained from the questionary and interview process with customer and employess of PT Bumi Hijau Puri Persada. The secondary data obtained from financial report of both income statement and statement of financial position year period 2015-2017. The result of this research indicate that the overall performance of PT Bumi Hijau Puri Persada is quite good with the score of 0,24. Financial perspective as measured by financial ratio analysis with score $(-0,33)$ is not good, which include a quite good liquidity ratio, quite good solvency ratio, a bad profitabilty ratio, and a good activity ratio.The result from the customer perspective indicate that the performance is quite good with score 0,56 consist of attributes of products services, company image, customer relationship. The internal business perspective also shows a good performance with a score of 0.57 which includes the process of innovation, operation, after sales service. Learning and growth side perspective show up with quite a good score of 0,57, consist of employee capabilities, information system capabilities, motivation, empowerment, harmony.
\end{abstract}

Keywords: Performance measurement, Balance Scorecard, Financial perspective, customer perspective, internal bussiness perspective, learning and growth perspective.

Dokumen diterima pada Selasa 16 April, 2019

Dipublikasikan pada Jumat 31 Mei, 2019 


\section{Pendahuluan}

Pada umumnya kinerja diukur secara tradisional yang hanya berdasarkan sisi finansial atau keuangan saja. Perusahaan dengan konsisi keuangan yang tinggi dianggap sebagai perusahaan yang berhasil. Terlebih lagi, kinerja yang hanya berdasarkan pada sisi finansial tidak dapat memberikan gambaran yang rill atau nyata mengenai kondisi perusahaan. Untuk mengatasi hal tersebut, kinerja perusahaan dapat dilihat melalui dua informasi yaitu keuangan dan non keuangan. Informasi keuangan berasal dari laporan keuangan suatu perusahaan. Sedangkan informasi non keuangan adalah kunci untuk menentukan strategi perusahaan. Para ahli telah banyak menerapkan beberapa model baru untuk sistem pengukuran kinerja seperti Performance Prism [11], Integrated Performance Measurement System, dan Balance Scorecard [4]. Menurut Neely, Adams, \& Kennerley [11] Performance Prism adalah model pengukuran kinerja yang membagi kinerja perusahaan sebagai suatu bangunan tiga dimensi yang terbagi dalam lima sisi yaitu kepuasan stakeholder, strategi, proses, kapabilitas, dan kontribusi stakeholder. Metode Performance Prism lebih menekankan kepada tuntutan stakeholder terhadap perusahaan serta kontribusi stakeholder yang diharapkan oleh perusahaan sebagai landasan untuk menentukan proses, kapabilitas, dan strategi perusahaan yang dianggap strategis untuk diukur. Dalam pengaplikasiannya, suatu organisasi dapat memfokuskan pada perspektif kontribusi dan tuntutan stakeholder yang merupakan perspektif utama dan perspektif lain dilakukan jika perspektif utama dinilai tidak memuaskan. Performance Prism tidak memiliki sistem pengukuran yang standar.

Selanjutnya, metode Integrated Performance Measurement System (IPMS) adalah suatu model pengukuran kinerja yang membagi perusahaan dalam empat level. Level tersebut terdiri dari bisnis, unit bisnis, proses bisnis dan aktivitas [1]. Model pengukuran kinerja ini sangat mengutamakan stakeholder. Balance Scorecard adalah model pengukuran kinerja terpopuler yang telah dikembangkan [10]. Balanced Scorecard menyediakan seperangkat instrumen yang dibutuhkan para manajer organisasi untuk mengelola organisasi menuju kepada keberhasilan persaingan di masa yang akan datang sesuai dengan arah strategi yang ingin dicapai. Balanced Scorecard dilengkapi seperangkat indikator kinerja finansial masa lalu dan indikator kinerja masa depan. Berbeda halnya dengan metode Performance Prism dan IPMS (Integrated Performance Measurement System) yang lebih berorientasi pada kepentingan stakeholder untuk memenuhi kepuasan yang diinginkan, Balance scorecard menyediakan kerangka kerja yang mampu menterjemahkan strategi kedalam kerangka kerja operasional. Balanced scorecard diperkenalkan oleh Robert Kaplan pada tahun 1992, sebagai konsep pengukuran manajemen yang berkembang. Konsep pengkuran kinerja tersebut kemudian dipertajam oleh Robert Kaplan dengan menetapkan pendekatan efektif yang "seimbang" (balanced) untuk mengukur kinerja. Pendekatan tersebut dibagi menjadi 4 (empat) perspektif, yaitu perspektif finansial, perspektif pelanggan, perspektif proses bisnis internal serta perspektif pembelajaran dan pertumbuhan. Menurut Mulyadi [9], Balance Scorecard adalah metode penilaian kinerja perusahaan dalam empat perspektif yaitu perspektif keuangan, pelanggan, proses bisnis internal, serta proses pembelajaran dan pertumbuhan yang melibatkan keuangan dan non keuangan.

Dalam perspektif keuangan, balance scorecard diterapkan untuk membantu tercapainya tujuan keuangan. Pada perspektif pelanggan, pelanggan segmen pasar yang akan dimasuki harus diperhatikan, untuk tujuan operasi yang nantinya kinerja akan diukur sesuai dengan target segmen tersebut. Pada perspektif proses bisnis internal manajeman harus mampu mengidentifikasi kinerja perusahaan secara internal karena proses internal memiliki nilai-nilai yang dinginkan konsumen serta tujuan yang diharapkan seluruh pemegang saham. Untuk perspektif pertumbuhan dan pembelajaran peningkatan value oleh karyawan sangat diharapkan. Kelebihan utama yang dimiliki oleh BSC adalah adanya pengukuran pada kinerja keuangan di mana uang merupakan darah bagi perusahaan, sehingga menjadi penting untuk mengukur pencapaian suatu perusahaan dalam aspek tersebut. Sejalan dengan hal tersebut, pencapaian keuntungan yang maksimal merupakan hal penting bagi perusahaan untuk rencana jangka panjang [13].

Dilihat dari fakta yang terjadi di Indonesia saat ini, sektor real estate merupakan bisnis 
Analisis Pengukuran Kinerja dengan Konsep Balance Scorecard

pada PT Bumi Hijau Puri Persada

yang berkembang pesat. Dalam Perkembangannya sektor tersebut bergantung terhadap modal dan investasi dari para investor. Hal tersebut terus meningkatkan kinerjanya agar para investor menjadi yakin dan percaya untuk berinvestasi. Hal ini akan menarik minat calon investor lainnya. PT Bumi Hijau Puri Persada merupakan perusahaan yang bergerak di bidang developer perumahan. Perusahaan ini berdiri pada tanggal 14 Agustus 2014 yang belokasi di Jalan Jendral Sudirman, Kelurahan Gajah Sakti, Kecamatan Mandau, Kota Duri, Kabupaten Bengkalis, Riau dengan nama perumahan Griya Bumi Hijau. Perusahaan ini menawarkan tiga tipe perumahan yaitu tipe 36 , tipe 45 , dan tipe 60 . Pada tahun 2014 , perusahaan memulai penjualannya pada tanggal 28 Agustus 2014 sampai 31 Desember 2014 dengan total penjualan sebesar 31 unit perumahan tipe 36 . Di tahun 2015, penjualan meningkat sebesar $75,78 \%$ dengan total penjualan 128 unit perumahan dengan tipe 36 . Di tahun 2016 penjualan meningkat sebesar $22,42 \%$ dengan total penjualan 165 unit perumahan tipe 36. Namun, di tahun 2017 penjualan hanya 90 unit perumahan tipe 36 dengan penurunan penjualan sebesar 45,5\%. Penurunan persentase penjualan yang hampir mencapai 50\% diyakini perusahaan sebagai kegagalan dalam penilaian kinerjanya. Sedangkan untuk perumahan tipe 45, dan tipe 60 masing-masing hanya dibangun sebanyak 3 unit dengan penjualan hanya terjadi di tahun 2015 sebanyak 1 unit untuk masing-masing tipe.

Dari segi persediaan perumahan, untuk tipe 36, tahun 2015 terdapat 17 unit ready stock diakhir tahun, tahun 2016 terdapat 6 unit ready stock diakhir tahun, dan tahun 2017 terdapat 25 unit ready stock diakhir tahun. Persediaan perumahan setiap tahunnya mengalami peningkatan dan penurunan. Kelebihan persediaan tentu saja mencerminkan rendahnya tingkat pengembalian investasi dan merupakan hal yang kurang produktif [3]. Selain itu, dalam menjalankan aktivitas operasinya, perusahaan belum pernah melakukan pengukuran kinerja menggunakan Balance Scorecard, tetapi perusahaan hanya menggunakan analisis laporan keuangan (rasio keuangan) seperti Return on Invenstment (ROI) dan Net Profit Margin. Penilaian kinerja yang hanya berdasarakan hal tersebut tentu saja belum mampu mewakili untuk menarik kesimpulan terhadap hasil yang telah dicapai. ROI dan Profit Margin dalam penggunaannya hanya mampu memperlihatkan penggunaan aktiva serta laba yang efektif selama periode yang dimaksudkan. Berdasarkan hal diatas untuk dapat menentukan kinerja, perusahaan dapat menerapkan Balance Scorecard sebagai alat ukur strategis yang menilai kinerja dengan perspektif yaitu keuangan, pelanggan, proses bisnis internal, serta proses pembelajaran dan pertumbuhan. Kelebihan penerapan Balance Scorecard adalah dapat memberikan patokan ukuran yang dapat dijadikan sebagai dasar dalam perbaikan perencanaan strategis perusahaan dalam menetapkan strategi dan pengalokasian sumber daya yang ada baik modal maupun manusia. Dari penjelasan tersebut, Peneliti tertarik untuk mengimplementasikan balanced scorecard untuk mengukur kinerja perusahaan ke dalam sebuah penelitian yang berjudul "Analisis Pengukuran Kinerja Perusahaan dengan Konsep Balance Scorecard pada PT Bumi Hijau".

\section{Tinjauan Pustaka}

\subsection{Kinerja Keuangan Perusahaan}

Kinerja merupakan gambaran mengenai sejauh mana keberhasilan atau kegagalan organisasi dalam menjalankan tugas dan fungsi pokoknya dalam rangka mewujudkan sasaran, tujuan, visi, dan misinya. Dengan kata lain, kinerja merupakan prestasi yang dapat dicapai oleh organisasi dalam periode tertentu. Kinerja adalah keberhasilan personil, tim, atau unit organisasi dalam mewujudkan sasaran strategik yang telah ditetapkan sebelumnya dengan perilaku yang diharapkan [8].

Penetapan strategi ditujukan untuk mampu menghasilkan perencanaan yang matang dan optimal. Pengukuran kinerja penting dan sangat dibutuhkan untuk mengetahui efektif atau tidaknya suatu strategi. Pengukuran kinerja merupakan suatu proses penilaian tentang kemajuan pekerjaan terhadap tujuan dan sasaran dalam pengelolaan sumber daya manusia untuk menghasilkan barang dan jasa, termasuk informasi atas efisiensi serta efektifitas tindakan dalam mencapai tujuan organisasi [7].

David P Norton dan Robert Kaplan memperkenalkan Balance Scorecard pada awal tahun 1990 di USA melalui riset tentang "pengukuran kinerja pada organisasi dimasa yang akan datang. 
"Istilah Balance Scorecard terdiri dari 2 kata yaitu balanced (berimbang) dan scorecard (kartu skor). Kata berimbang (balanced) dapat diartikan dengan kinerja yang diukur yang diukur secara berimbang dari dua sisi yaitu sisi keuangan dan sisi non keuangan, mencakup jangka pendek dan jangka panjang serta melibatkan bagian internal dan eksternal, sedangkan kata kartu skor ( scorecard) merupakan suatu kartu yang digunakan untuk mencatat perencanaan dimasa yang akan datang [12].

\subsection{Perspektif Balance Scorecard}

\subsubsection{Perspektif Keuangan}

Pada aspek keuangan memakai tolak ukur kinerja keuangan yaitu menggunakan analisis rasio keuangan:

a. Rasio Likuiditas

Terdapat tiga rasio likuiditas yang akan digunakan diantaranya adalah current ratio, cash ratio, dan quick ratio. Current Ratio merupakan rasio untuk mengukur kewajiban perusahaan dalam membayar kewajiban jangka pendek atau utang yang segera jatuh tempo pada saat ditagih secara keseluruhan. Berikut rumus yang digunakan [2]:

$$
\text { Current Ratio }=\frac{\text { Aset Lancar }}{\text { Utang Lancar }}
$$

Cash Ratio atau rasio kas merupakan alat yang digunakan untuk mengukur seberapa besar uang kas yang tesedia untuk membayar utang [6].

$$
\text { Cash Ratio }=\frac{\text { Kas dan Setara Kas }}{\text { Kewajiban Lancar }}
$$

Quick Ratio (rasio cepat) merupakan rasio yang menunjukkan kemampuan perusahaan dalam memenuhi atau membayar kewajiban atau hutang jangka pendek dengan aktiva lancar tanpa memperhitungkan nilai persediaan atau inventory [6].

$$
\text { Quick Ratio }=\frac{\text { Aset Lancar-Persediaan }}{\text { Kewajiban Lancar }}
$$

b. Rasio Solvabilitas atau Leverage

Terdapat dua rasio solvabilitas atau leverage yang akan digunakan diantaranya adalah Debt to Asset Ratio, dan Debt to Equity Ratio. Debt ratio to Asset merupakan rasio yang digunakan untuk mengukur seberapa besar aktiva perusahaan dibiayai oleh utang atau seberapa besar utang perusahaan berpengaruh terhadap pengelolaan aktiva [6].

$$
\text { Debt to Asset Ratio }=\frac{\text { Total Liabilities }}{\text { Total Aset }}
$$

Debt to Equity Ratio merupakan rasio yang digunakan untuk menilai utang dengan ekuitas. Rasio ini dicari dengan cara membandingkan antara seluruh utang, termasuk utang lancar dengan seluruh ekuitas [6].

$$
\text { Debt to Equity Ratio }=\frac{\text { Total Liabilities }}{\text { Total Equity }}
$$

c. Rasio Profitabilitas

Terdapat dua rasio profitabilitas yang akan digunakan diantaranya adalah Net Profit Margin dan Return On Investment. Net Profit Margin merupakan Rasio yang digunakan untuk mengukur margin laba atas penjualan, rasio ini akan menggambarkan penghasilan bersih perusahaan berdasarkan total penjualan [2].

$$
\text { Margin Laba Bersih }=\frac{\text { Laba Bersih }}{\text { Penjualan }}
$$

Hasil pengembalian investasi atau lebih dikenal dengan nama return on investment (ROI) atau return on assets (ROA) merupakan rasio yang menunjukkan hasil (return) atas jumlah aktiva yang digunakan dalam perusahaan [6].

$$
R O I=\frac{\text { Laba Bersih }}{\text { Total Asset }}
$$


Analisis Pengukuran Kinerja dengan Konsep Balance Scorecard

pada PT Bumi Hijau Puri Persada

d. Rasio Aktivitas

Terdapat dua rasio aktivitas yang akan digunakan diantaranya adalah Total Asset Turn Over dan Inventory Turn Over. Total Asset Turn Over merupakan rasio yang digunakan untuk mengukur perputaran semua aset yang dimiliki perusahaan dan mengukur berapa jumlah penjualan yang diperoleh dari tiap rupiah asset [3].

$$
\text { TATO }=\frac{\text { Penjualan }}{\text { Total Asset Tetap }}
$$

Perputaran persediaan (Inventory Turn Over) merupakan rasio yang digunakan untuk mengukur berapa kali dana yang ditanam dalam persediaan berputar dalam suatu persediaan. Semakin kecil rasio ini, semakin jelek demikian pula sebaliknya. Rasio ini dirumuskan [6]:

$$
\text { ITO }=\frac{\text { Penjualan }}{\text { Persediaan }}
$$

\subsubsection{Perspektif Pelanggan}

Dalam aspek ini, pelanggan menjadi objek pengukurannya. Aspek ini bertujuan untuk mengukur meningkatnya kepercayaan klien atas produk dan jasa yang dipromosikan perusahaan, kecepatan layanan yang diberikan dan kualitas hubungan perusahaan dengan kliennya. Informasi yang diketahui tentang seberapa baik hubungan yang dimiliki perusahaan dengan kliennya dapat memberikan gambaran bagaimana suatu kinerja manajemennya berjalan dengan baik atau tidak. Pengukuran dilakukan melalui kuesioner dengan Skala likert.

\subsubsection{Perspektif Bisnis Internal}

Tahapan dalam proses bisnis internal meliputi Inovasi, Proses Operasi, dan Layanan Purna Jual [4]. Dalam aspek ini diukur dengan melalui kuesioner terhadap seluruh proses. Dalam inovasi meliputi produk apa saja yang telah dikembangkan, proses operasi meliputi waktu pengerjaan hingga sampai pada proses penyampaian produk ke konsumen. Selain itu, pada purna jual meliputi transaksi setelah pembelian baik garansi maupun reparasi. Pengukuran dilakukan melalui kuesioner dengan Skala likert.

\subsubsection{Perspektif Pertumbuhan Pembelajaran}

Ada tiga hal yang perlu ditinjau dalam menerapkan balance scorecard yaitu Kapabilitas Karyawan, Kapabilitas Sistem Informasi dan Motivasi, Pemberdayaan dan Keselarasan [5]. Tujuan dari perspektif pembelajaran dan pertumbuhan adalah menyediakan infrastruktur untuk mendukung pencapaian tiga perspektif sebelumnya. Kapabilitas karyawan menyangkut apa saja yang diberikan karyawan kepada perusahaan. Hal yang harus diperhatikan dalam aspek ini yaitu kepuasan karyawan dimana hal ini sangat penting bagi perusahaan dalam menjalankan aktivitas operasinya. Kapabilitas Sistem Informasi berhubungan dengan perusahaan yang menyediakan segala informasi dan sistem yang dapat mempermudah karyawan dalam menjalankan tugasnya. Motivasi mewakili proses-proses tertentu yang menyebabkan timbulnya, diarahkannya, dan terjadinya kegiatan tertentu untuk diarahkan ke tujuan tertentu. Untuk meningkatkan kinerja diperlukan suatu pengembangan keahlian yang dapat memompa potensi diri yang dimiliki oleh pekerja/karyawan. Sehingga pemberdayaan tadi dapat menyelaraskan tiap-tiap kegiatan perusahaan pada tujuan yang ingin dicapai perusahaan. Pengukuran dilakukan melalui kuesioner dengan Skala likert.

\section{Metodologi Penelitian}

\subsection{Lokasi Penelitian}

Lokasi penelitian dalam kasus PT Bumi Hijau Puri Persada Duri beralamat di Jalan Bumi Hijau-Stadion, yang berkelurahan di Air Jamban, dengan Kecamatan Mandau, di Kota Duri, Kab. Bengkalis.

\subsection{Jenis dan Sumber Data}

Sumber data terdiri dari data primer dan sekunder. Menurut Sugiyono [14] data primer adalah jenis data yang memberikan informasi secara langsung, dan data sekunder adalah data 
yang informasinya diberikan secara tidak langsung. Data primer dalam penelitian ini yaitu berupa penyebaran kuesioner dan wawancara dengan jenis data kualitatif, sedangkan data sekunder berupa laporan keuangan dan catatan dokumentasi perusahaan dengan jenis data kuantitatif.

\subsection{Teknik Pengumpulan Data}

Dalam penelitian ini, teknik pengumpulan data dan informasi yang dilakukan penulis adalah menggunakan Teknik wawancara dan penyebaran kuesioner serta dokumentasi. Data yang relevan diperlukan untuk dapat menetukan jawaban pada kuesioner. Karena itu, akan dilakukan wawancara terhadap para karyawan dengan mencari data yang berhubungan seperti dokumen, laporan keuangan (laba rugi), serta membagikan kuisioner kepada pelanggan dan karyawan untuk dapat mengetahui tingkat kepuasan.

Pengukuran yang dilakukan dengan kuesioner untuk perspektif Pelanggan dan Pertumbuhan Pembelajaran menggunakan skala likert untuk mengukur sikap, pendapat dan persepsi seseorang atau sekelompok orang tentang fenomena sosial [15]. Pilihan untuk masingmasing jawaban terhadap tanggapan responden atas kepuasan yaitu bobot nilai 5 berarti sangat puas, bobot nilai 4 berarti puas, bobot nilai 3 berarti kurang puas, bobot nilai 2 berarti tidak puas, dan bobot nilai 1 berarti sangat tidak puas. Demikian juga halnya pada pengukuran perspektif bisnis internal, pilihan untuk masing-masing jawaban terhadap tanggapan responden yaitu bobot nilai 5 berarti sangat setuju, bobot nilai 4 berarti setuju, bobot nilai 3 berarti kurang setuju, bobot nilai 2 berarti tidak setuju, dan bobot nilai 1 berarti sangat tidak setuju.

\subsection{Analisis Data}

Analisis data yang digunakan yaitu metode deskriptif kuantitatif, dilakukan dengan cara:

\section{Pengolahan Data}

Pengolahan data yang menggunakan kuesioner akan melalui pengujian instrumen penelitian melalui SPSS, yaitu akan dilakukan uji validitas untuk mengukur apakah pertanyaan pada kuesioner tersebut mampu mengungkapkan sesuatu diinginkan untuk diukur pada kuesioner tersebut. Suatu variabel akan dikatakan valid jika signifikan terhadap skor total $<0,05$. Selain uji validitas, akan dilakukan uji reliabilitas untuk mengukur keandalan suatu kuesioner. Uji reliabilitas akan dilakukan dengan uji statistik cronbach alpha. Suatu variabel akan dikatakan reliabel jika memberikan nilai Cronbach Alpha >0,60.

Perspektif keuangan diukur dengan menggunakan rasio keuangan sedangkan agar dapat diperoleh hasil mengenai kepuasan pelanggan, dan kepuasan karyawan, serta pengukuran perspektif bisnis internal data pengisian kuesioner akan diubah menjadi data angka atau kuantitatif dengan menggunakan skor untuk semua jawaban berdasarkan skala likert 1 sampai 5, menurut Sugiyono [15] Untuk menentukan skala likert tersebut terlebih dahulu ditentukan indeks kepuasan minimal dan indeks kepuasan maksimal, interval yang dapat dicari dari pengurangan antara indek kepuasan maksimal dengan indek kepuasan minimal dibagi menjadi lima yaitu [15]:

IK maks $\quad=\mathrm{R} \times \mathrm{PP} \times \mathrm{EX}$ maks

IK $\min \quad=\mathrm{R} x$ PP $x$ EX min

Interval $\quad=(\mathrm{IK}$ maks $-\mathrm{IK}$ min $) \div$ skala skor

Keterangan:

$\mathrm{PP}=$ Banyaknya pertanyaan

$\mathrm{R}=$ Jumlah responden

EX min = Skor minimal yang bisa diberikan

EX maks = Skor maksimal yang bisa diberikan

IK min $=$ Indeks kepuasan minimal

IK maks = Indeks kepuasan maksimal

2. Penyajian Data

Setelah proses pengolahan data dengan SPSS, selanjutnya data dianalisis lagi, disusun dan disajikan dalam bentuk tabel, serta diuraikan secara deskriptif.

3. Pengambilan Kesimpulan

Pengambilan kesimpulan dilakukan pada masing masing perspektif dimana, pada perspektif keuangan kesimpulan diambil berdasarkan perhitungan analisis rasio keuangan likuiditas, solvabilitas, 
Analisis Pengukuran Kinerja dengan Konsep Balance Scorecard pada PT Bumi Hijau Puri Persada

profitabilitas, dan aktivitas yang dibandingkan dari tahun 2015 sampai tahun 2017. Dalam perspektif Pelanggan, perspektif bisnis internal, dan perspektif pertumbuhan pembelajaran, kesimpulan diambil berdasarkan perhitungan kuesioner yang diubah kedalam data angka berdasarkan skala likert. Setelah pengukuran kinerja didapat dari masing-masing perspektif, selanjutnya ukuran kinerja tersebut akan digunakan untuk mengukur kinerja perusahaan secara keseluruhan dengan menggunakan rating scale. Menurut Sugiyono [15] dengan rating scale data mentah yang diperoleh berupa angka akan ditafsirkan kedalam pengertian kualitatif.

Menurut Mulyadi [9] untuk mengukur keseimbangan yang dicapai dalam setiap perspektif digunakan kriteria kesimbangan. Adapun skor dalam tabel kriteria keseimbangan adalah skor standar, jika kinerja semua aspek dalam perusahaan adalah "baik". Skor diberikan berdasarkan rating scale berikut [9]:

Tabel 1 Rating Scale BSC
\begin{tabular}{|c|c|}
\hline Skor & Nilai \\
\hline-1 & Kurang \\
\hline 0 & Cukup \\
\hline 1 & Baik \\
\hline
\end{tabular}

Pada masing-masing perspektif yang telah diberi rating scale, kemudian akan dicari rata-rata dari nilai kinerja perusahaan. Kinerja yang dapat dikatakan baik adalah lebih dari $80 \%$ yang diasumsikan sama dengan 0,6 . Sedangan batas cukup adalah kinerja yang nilainya antara $0-0,6$ [9]. Setelah dirata-rata maka akan diperoleh kesimpulan kinerja perusahaan dengan kategori kurang baik, cukup baik, dan baik.

\section{Hasil Pembahasan}

\subsection{Pengukuran Kinerja Perusahaan dengan Balance Scorecard}

Berikut adalah rangkuman perhitungan kinerja perusahaan dengan Balance Scorecard yang terdiri dari perspektif keuangan, perspektif pelanggan, perspektif bisnis internal dan perspektif pertumbuhan dan pembelajaran pada tabel 2:

Tabel 2 Hasil Penilaian BSC Secara Keseluruhan

\begin{tabular}{|c|c|c|c|c|c|c|c|c|c|}
\hline \multirow[b]{2}{*}{ Perspektif } & \\
\hline & 2015 & Kriteria & Skor & 2016 & Kriteria & Skor & 2017 & Kriteria & Skor \\
\hline \multicolumn{10}{|c|}{ PERSPEKTIF KEUANGAN } \\
\hline \multicolumn{10}{|l|}{ Likuiditas } \\
\hline Current & 2,75 & $\mathrm{~B}$ & 1 & 3,02 & $\mathrm{CB}$ & 0 & 3,60 & $\mathrm{CB}$ & 0 \\
\hline Cash & 0,22 & $\mathrm{~K}$ & -1 & 0,29 & $\mathrm{~K}$ & -1 & 0,16 & $\mathrm{~K}$ & -1 \\
\hline Quick & 2,56 & $\mathrm{~B}$ & 1 & 2,92 & $\mathrm{~B}$ & 1 & 3,02 & $\mathrm{~B}$ & 1 \\
\hline & $\mathrm{TO}$ & TAL & 1 & & TAL & 0 & & DTAL & 0 \\
\hline \multicolumn{7}{|c|}{ Rata-rata rasio likuiditas } & \multicolumn{3}{|c|}{$\mathbf{0 , 3 3}$} \\
\hline \multicolumn{10}{|l|}{ Solvabilitas } \\
\hline $\begin{array}{c}\text { Debt to } \\
\text { asset }\end{array}$ & 0,93 & K & -1 & 0,89 & K & -1 & 0,82 & K & -1 \\
\hline $\begin{array}{c}\text { Debt to } \\
\text { equity }\end{array}$ & 14,23 & K & -1 & 8,42 & K & -1 & 4,68 & CB & 0 \\
\hline & & TAL & -2 & & TAL & -2 & & DTAL & -1 \\
\hline \multicolumn{7}{|c|}{ Rata-rata rasio solvabilitas } & \multicolumn{3}{|c|}{$-1,67$} \\
\hline \multicolumn{10}{|c|}{ Profitabilitas } \\
\hline$N P M$ & $9,46 \%$ & K & -1 & $\begin{array}{l}11,1 \\
6 \% \\
\end{array}$ & K & -1 & $\begin{array}{l}10,1 \\
1 \% \\
\end{array}$ & K & -1 \\
\hline ROI & $6,7 \%$ & $\mathrm{~K}$ & -1 & $6,6 \%$ & $\mathrm{~K}$ & -1 & $4,1 \%$ & $\mathrm{~K}$ & -1 \\
\hline & \multicolumn{2}{|c|}{ TOTAL } & -2 & \multicolumn{2}{|c|}{ TOTAL } & -2 & \multirow{2}{*}{\multicolumn{2}{|c|}{$\begin{array}{r}\text { TOTAL } \\
\mathbf{2}\end{array}$}} & -2 \\
\hline & $\mathbf{R a}$ & a-rata ras & o profi & abilitas & & & & & \\
\hline
\end{tabular}


16

Elisa Silviana, Suci Nurulita dan Heri Ribut Yuliantoro

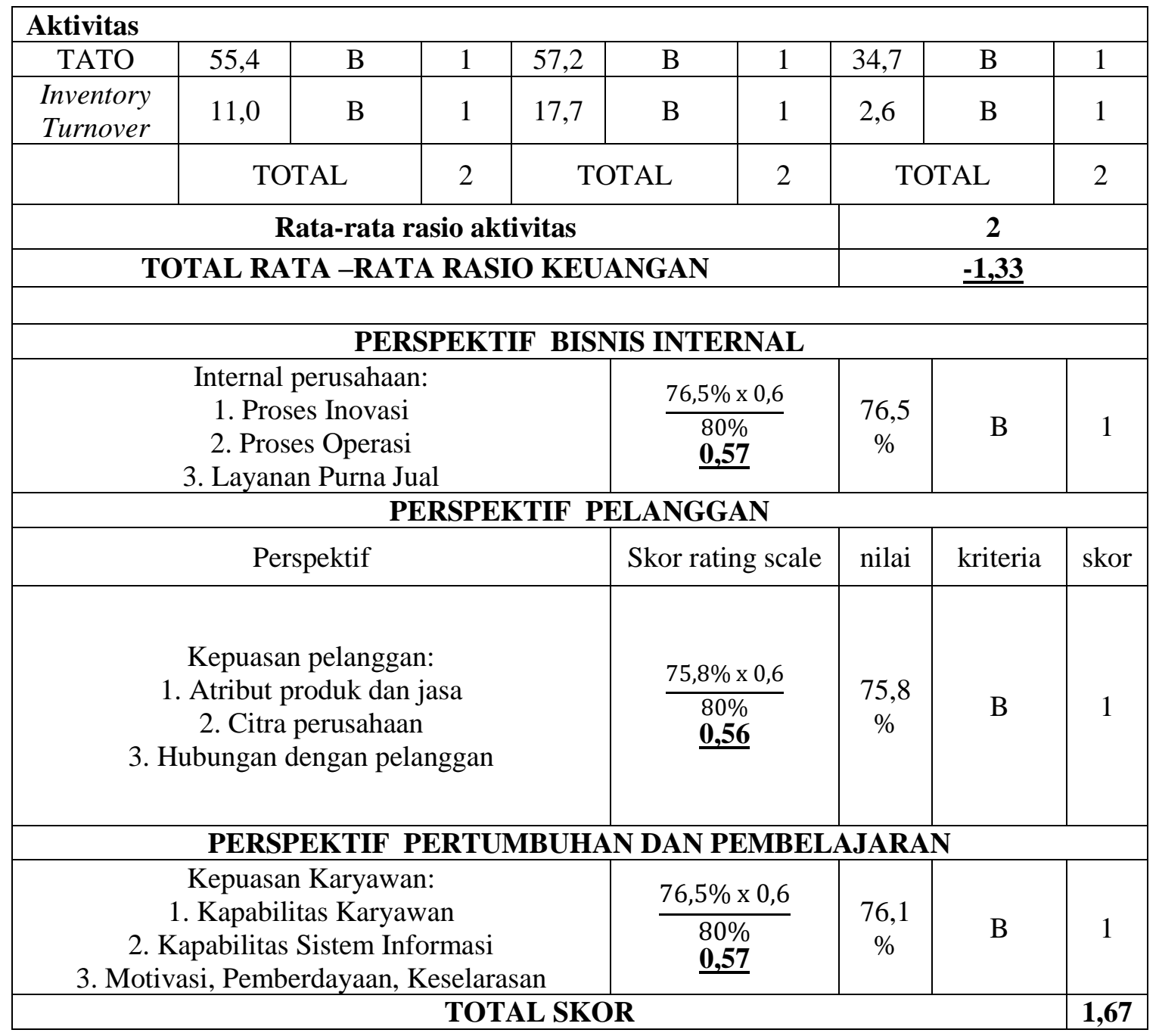

Sumber: data olahan, 2018.

Dari tabel diatas, total skor yang ditunjukkan dalam mengukur keseimbangan keempat perspektif adalah 1,67 dari 7 item yang dinilai. Rata- rata skor yang didapat adalah 0,24 (1,67/7). Berikut merupakan batas keimbangan dengan skor standar:

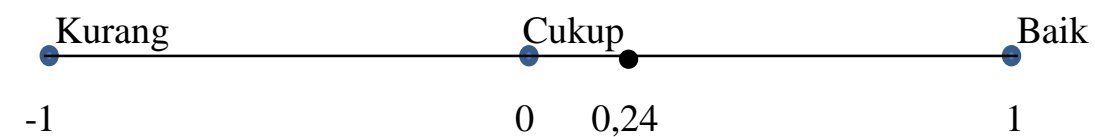

Gambar No. 1 Rating Scale

Kinerja yang dapat dikatakan baik adalah lebih dari $80 \%$ yang diasumsikan sama dengan 0,6 . Sedangan batas cukup adalah kinerja yang nilainya antara $0-0,6$. Berdasarkan gambar, dapat dilihat bahwa kinerja PT Bumi Hijau Puri Persada hanya bernilai 0,24 yang artinya berada antara 0 - 0,6 sehingga kinerja PT Bumi Hijau Puri Persada dapat dikatakan cukup baik.

Dari tabel diatas, dapat diketahui bahwa pada perspektif keuangan, rata-rata penilaian menunjukkan nilai kurang baik dengan nilai rata-rata $-0,33(-1,33 / 4)$. Penilaian kinerja yang kurang baik pada perspektif keuangan disebabkan oleh rasio solvabilitas dan rasio profitabilitas perusahaan yang kurang baik. Dalam tabel diatas, diketahui bahwa solvabilitas perusahaan yang setiap tahunnya mengalami penurunan dimana penurunan tersebut menggambarkan bahwa setiap tahun baik rasio utang terhadap aset maupun ekuitas semakin baik. Akan tetapi, rasio perusahaan yang jauh diatas rata-rata industri yang berarti bahwa hampir secara keseluruhan perusahaan dibiayai dengan utang mengakibatkan kondisi perusahaan dinilai kurang baik. Selain itu, 
Analisis Pengukuran Kinerja dengan Konsep Balance Scorecard

pada PT Bumi Hijau Puri Persada

profitabilitas atau tingkat keuntungan PT Bumi Hijau Puri Persada menunjukkan hasil yang kurang baik (perusahaan tidak mampu mencapai keuntungan). Meskipun dalam rasio ini ada terjadi kenaikan pada tahun 2016, tetapi rasio tersebut masih jauh dibawah rata-rata industri sehingga dapat dinilai kurang baik. Sedangkan penilaian yang dikategorikan baik terdapat pada rasio aktivitas yang menunjukkan bahwa perusahaan mampu memaksimalkan aset yang dimiliki sehingga rasio yang dihasilkan melebihi rata-rata industri dan meskipun ada penurunan, rasio tersebut tetap baik karena lebih dari rata-rata industrinya.

Selain dari perspektif keuangan, perspektif non keuangan memberikan nilai yang cukup baik bagi perusahaan terutama pada perspektif bisnis internal dan perspektif pertumbuhan pembelajaran. Pada perspektif bisnis internal, dukungan karyawan terhadap inovasi dan solusi yang ditawarkan perusahaan kepada pelanggan menerima respon yang positif serta layanan purna jual yang menambah nilai pelayanan untuk perusahaan dimana layanan purna jual harus memiliki aturan atau kesepakatan dengan pembeli sehingga kesalahpahaman dapat diminimalisir. Ketidaksetujuan dalam perspektif ini terletak pada karyawan yang merasa bahwa layanan purna jual hanya akan menghambat aktivitas perusahaan karena banyaknya keluhan.

Pada perspektif pertumbuhan pembelajaran, tanggapan positif dari kepuasan karyawan ditujukan kepada aspek perusahaan yang menghargai karyawannya dalam berkarya, berkreativitas dan terbukanya perusahaan akan usulan atau tanggapan semua karyawannya. Selanjutnya, adanya teknologi informasi yang memadai sehingga kebutuhan karyawan dapat terpenuhi dan perusahaan juga memberikan imbalan berupa bonus kepada karyawan yang berprestasi. Ketidakpuasan karyawan terletak pada beberapa karyawan yang merasa gaji tidak sesuai dengan tanggungjawab yang dijalankan, dan adanya penyampaian informasi yang tidak merata untuk setiap karyawan.

Perspektif pelanggan juga memberikan nilai yang cukup baik, tetapi nilainya sedikit lebih rendah dibandingkan dua perspektif non keuangan lainnya. Berdasarkan penilaian terhadap kepuasan pelanggan, aspek kepuasan terletak pada harga produk yang terjangkau, pelayanan pasca transaksi yang baik dari perusahaan, kesesuaian produk jadi dengan permintaan pelanggan, dan ketepatan waktu penyelesaian produk. Hal yang menjadi sumber ketidakpuasan pelanggan terletak pada pelanggan yang merasa material yang digunakan kurang baik, serta beberapa pelanggan yang menyatakan bahwa pelayanan perusahaan atas keluhan mereka tidak sesuai harapan.

\section{Kesimpulan danSaran}

\subsection{Kesimpulan}

Berdasarkan pengukuran kinerja dengan konsep Balance Scorecard pada PT Bumi Hijau Puri Persada meliputi perspektif keuangan, pelanggan, bisnis internal, dan pertumbuhan pembelajaran, diperoleh ukuran kinerja secara keseluruhan yaitu sebesar 0,24 yang berarti kinerja perusahaan cukup baik. Adapun kesimpulan penilaian masing-masing perspektif:

a. Hasil pengukuran kinerja keuangan menunjukkan nilai yang kurang baik dengan rata-rata nilai sebesar (-1,33). Rasio likuiditas menunjukkan kinerja yang cukup baik dengan rata-rata nilai 0,33. Rata-rata rasio Solvabilitas menunjukkan nilai yang kurang baik yaitu sebesar (1,67). Namun, dalam pengukuran dengan rasio profitabilitas didapat bahwa kinerja perusahaan kurang baik dengan rata-rata nilai sebesar (-2). Akan tetapi, rasio aktivitas menunjukkan hasil yang baik dengan nilai pengukuran sebesar 2 .

b. Pada perspektif pelanggan, pengukuran kinerja yang didapat sebesar 75,8\% atau 0,56 yang artinya kinerja perusahaan dalam memenuhi kepuasan pelanggan cukup baik.

c. Pada perspektif proses bisnis internal, pengukuran kinerja yang didapat sebesar 76,5\% atau 0,57 yang artinya kinerja perusahaan dalam kegiatan internalnya cukup baik.

d. Pada perspektif pertumbuhan pengukuran kinerja yang didapat sebesar 76,1\% atau 0,57 yang artinya kinerja perusahaan dalam memenuhi kepuasan karyawannya cukup baik. 


\subsection{Saran}

Adapun saran yang dapat diberikan berdasarkan hasil penelitian ini adalah sebagai berikut:

a. Pada perspektif keuangan, tingkat pengembalian / keuntungan perusahaan (profitabilitas) masih belum tercapai sehingga perlu adanya penekanan terhadap biaya-biaya operasi seperti biaya promosi, biaya perjalanan dinas, dan lain-lain. Selain itu, perusahaan dapat meningkatkan harga jual yang juga disesuaikan dengan kondisi (baik dari segi biaya material maupun tenaga kerjanya). Dari sisi kewajiban perusahaan, perlu adanya kebijakan terhadap peminjaman dana kepada pihak ketiga dengan menyesuaikan tingkat pengembalian yang dapat diberikan sehingga resiko tidak mampu melunasi utang dapat diperkecil dan beban bunga yang ditanggung juga dapat diperkecil. Persediaan juga merupakan hal yang perlu diperhatikan dimana persediaan yang berlebihan dapat menyebabkan perusahaan menjadi tidak produktif, sehingga perlu dilakukan pengontrolan atau perencanaan persediaan.

b. Pada perspektif pelanggan, kepuasan pelanggan merupakan hal yang utama sehingga perlu menjaga hubungan baik dengan pelanggan dan terus mempertahankan pelayanan yang baik terutama pada aspek atribut produk dan jasa yang ditawarkan yaitu kualitas dari perumahan, dan layanan pasca transaksi terhadap tanggapan atas keluhan atau kendala sehingga pelanggan dapat merasa puas.

c. Pada perspektif bisnis internal, kekompakan dan peranan karyawan sangat diperlukan karena kondisi intenal yang baik akan mampu mengarahkan perusahaan dalam mencapai tujuannya.

d. Perspektif pertumbuhan pembelajaran mengutamakan kepuasan karyawan terhadap perusahaan sehingga perusahaan harus mampu menjaga hubungan baik dengan karyawan dan dapat memberikan kenyamanan serta dukungan bagi karyawan agar dapat mencapai peningkatan laba yang signifikan.

\section{Daftar Pustaka}

[1] Bititci, U., Carrie, A., \& McDevitt, L. Integrated performance measurement systems: a development guide. International Journal of Operations \& Production Management, Vol.17, 1997.

[2] Gibson, C. H.. Financial reporting \& Analysis. USA: South-Western Cengage Learning, 2008.

[3] Hanafi, M., \& Halim, A. Analisis Laporan Keuangan. Edisi Kelima. Yogyakarta: UPP AMP YKPN, 2016.

[4] Kaplan, R. S., \& David P. Norton. Balanced Scorecard: Menerapkan Strategi Menjadi Aksi. Jakarta: Erlangga, 1996.

[5] Kaplan, R. S., \& Norton. The Strategy Focused Organization: How Balanced Scorecard Companies Thrive in the New Business Environment. Massachusetts: Harvard Business School Press, 2001.

[6] Kasmir. Analisis Laporan Keuangan. Jakarta: Rajawali Pers, 2016.

[7] Moeheriono. Pengukuran Kinerja Berbasis Kompetensi. Jakarta: Raja Grafindo Persada, 2012.

[8] Mulyadi. Akuntansi Manajemen : Konsep, Manfaat dan Rekayasa. Jakarta: Salemba Empat, 2001.

[9] Mulyadi. Sistem Terpadu Pengelolaan Kinerja Personal Berbasis Balanced Scorecard. Jakarta: Salemba Empat, 2009.

[10] Neely, A. D., Gregory, M., \& Platts, K. Performance Measurement System Design: Aliterature Review and Research Agenda. International Journal of Operations \& Production Management 15(4), 80-116, 1995.

[11] Neely, A., Adams, C., \& Kennerley, M. The Performance Prism: The Scorecard for Measuring and Managing Business Success. London: Financial Times/Prentice Hall, 2002.

[12] Rangkuti, F. SWOT Balanced Scorecard. Jakarta: PT Gramedia Pustaka Utama, 2011.

[13] Simbolon, F. Perbandingan Sistem Pengukuran Kinerja Perusahaan. Binus Business Review, 91-100, 2015.

[14] Sugiyono. Metode Penelitian Kuantitatif Kualitatif dan R\&D. Bandung: Alfabeta, 2012.

[15] Sugiyono. Metode Penelitian Kuantitatif Kualitatif \& RND. Bandung: Alfabeta, 2017. 